\title{
RELATIVE LAMB-MÖSSBAUER FACTORS OF TIN CORROSION PRODUCTS
}

\author{
M.T. SOUGRATI, S. JOUEN* and B. HANNOYER. \\ Laboratoire d'Analyse Spectroscopique et de Traitement de Surface des Matériaux \\ Institut des Matériaux, Université de Rouen B.P. 12 \\ 76801 Saint Etienne du Rouvray Cedex, France \\ Corresponding author: samuel.jouen@univ-rouen.fr
}

\begin{abstract}
Variable temperature ${ }^{119} \mathrm{Sn}$ Mössbauer spectroscopy was used to obtain relative LambMössbauer factors for three tin corrosion products: hydrated stannic oxide $\mathrm{SnO}_{2} \cdot \mathrm{xH}_{2} \mathrm{O}$, abhurite $\mathrm{Sn}_{3} \mathrm{OCl}_{2}(\mathrm{OH})_{2}$, and tin hydroxysulfate $\mathrm{Sn}_{3} \mathrm{OSO}_{4}(\mathrm{OH})_{2}$. Their hyperfine parameters have also been investigated.
\end{abstract}

Key words: Lamb-Mössbauer factor, tin, corrosion products.

\section{Introduction}

The use of tin in many industrial fields has become increasingly important. Thin tin coatings are used in solders, marine equipments, roofing, gasoline tanks, exhaust pipes and, more widely, coating of steel in canning industry. As a consequence of this usage, the tin comes in contact with an innumerable variety of environments [1]. Thus the understanding of the corrosion mechanism is required to develop any protection protocol. Mössbauer spectroscopy can provide precious information on the corrosion process. It allows the characterisation of the phases resulting on the tin corrosion [2], and permits their quantification [3]. The identification of the corrosion products is deduced from the hyperfine parameters. The quantification is conditioned by the knowledge of the Lamb-Mössbauer factors e.g. $f$-factor. Therefore, reliable analysis of the corrosion layer requires an accurate determination of both the hyperfine parameters and Lamb-Mössbauer factors of the formed phases. The hyperfine parameters have been published for the principle tin compounds. Unfortunately, only few $f$-factor values are available for tin compounds and the essential published results concern metallic tin oxides. Also, for the same compound the value of Lamb-Mössbauer factor varies following the preparation method. The work of Collins and his collaborators, [4], illustrates clearly the impact of the crystallinity on both the Mössbauer parameters and the $f$-factor of tin oxides.

The purpose of this work is to give a complete Mössbauer study of three tin corrosion products. The hydrated stannic oxide $\mathrm{SnO}_{2} \cdot \mathrm{xH}_{2} \mathrm{O}$ is formed during outdoor corrosion of metallic tin and tin bronzes [5], the abhurite $\mathrm{Sn}_{3} \mathrm{OCl}_{2}(\mathrm{OH})_{2}$ has been detected as a corrosion product of tin formed in seawater [6] and tin hydroxysulfate $\mathrm{Sn}_{3} \mathrm{OSO}_{4}(\mathrm{OH})_{2}$ which is expected to form in atmospheres containing notable amount of sulphur dioxide [7].

\section{Experimental}


In the ideal case, only natural corrosion products must be investigated. However, except for natural hydrated stannic oxide, it was not possible to get sufficient quantity of natural compounds for Mössbauer measurement. Hence, electrochemically synthesised tin hydroxysulfate and abhurite have been used. XRD examination shows that the resulting products are of high crystallinity with orthorhombic and trigonal system respectively for tin hydroxysulfate and abhurite.

The variable temperature Mössbauer experiments were carried out in the 15-300 K temperature range on powdered samples. The source used was a ${ }^{119 m} \mathrm{Sn}(\mathrm{CaSnO} 3)$ source $(10 \mathrm{mCi})$ with a conventional constant acceleration spectrometer. The analysed samples contain $10 \mathrm{mg} . \mathrm{cm}^{-2}$ of natural tin nuclei. The chemical isomer shift data are quoted relative to the centroid of $\mathrm{BaSnO}_{3}$ spectrum at room temperature.

\section{Results}

\section{3-1. Hyperfine parameters}

The Mössbauer hyperfine parameters obtained at room temperature for $\mathrm{SnO}_{2} \cdot \mathrm{xH}_{2} \mathrm{O}$, table 1, are in good agreement with literature data $[10,11]$. The data obtained for $\mathrm{Sn}_{3} \mathrm{OSO}_{4}(\mathrm{OH})_{2}$ are slightly different from those found by Davies and Donaldson [12] $\left(\delta=2.57 \mathrm{~mm} \cdot \mathrm{s}^{-1}, \Delta=2.00 \mathrm{~mm} . \mathrm{s}^{-1}\right)$. No data have been found in the literature for $\mathrm{Sn}_{3} \mathrm{OCl}_{2}(\mathrm{OH})_{2}$ A typical spectrum for each compound is shown in figure 1 Spectrum (a) contains, in addition to $\mathrm{SnO}_{2} \cdot \mathrm{xH} 2 \mathrm{O}$ subspectrum, a second component at $\delta=2.508 \mathrm{~mm} \cdot \mathrm{s}^{-}$

${ }^{1}$ which is assigned to metallic tin. $\mathrm{Sn}_{3} \mathrm{OSO}_{4}(\mathrm{OH})_{2}$ spectrum consists on a single asymmetric doublet (b). $\mathrm{Sn}_{3} \mathrm{OCl}_{2}(\mathrm{OH})_{2}$ spectrum is also an asymmetric doublet, but a small peak is observed around $\delta=0.0$ $\mathrm{mm} . \mathrm{s}^{-1}$ indicating the formation of Sn(IV) compound (c). The relative area of this peak is less than $2 \%$ of the spectrum.

\section{3-2. Lamb-Mössbauer factor $(f$-factor $)$}

When the corrosion products are clearly identified, Mössbauer spectroscopy can be used for quantitative analysis. For this purpose relative Lamb-Mössbauer factors are required. In the case of thin absorber, the temperature dependence of the Lamb-Mössbauer factor can be represented by the temperature dependence of the area under the resonance curve [13]. In the Debye model and in the high-temperature limit, one can write [10]:

$$
\frac{d}{d T}(\ln \quad A)=\frac{d}{d T}(\ln f)=\frac{-6 E_{R}}{k_{B} \theta_{M}^{2}}
$$

Where $A$ is the area under the resonance curve, $E_{R}=2.57 \mathrm{MeV}$ is the recoil energy for ${ }^{119} \mathrm{Sn}, \theta_{\mathrm{M}}$ is the Debye temperature of the solid and $\mathrm{k}_{\mathrm{B}}$ is the Boltzmann constant.

Figure 2 displays the temperature dependence of the area, normalised to the area at $\mathrm{T}_{0}=15 \mathrm{~K}$, for $\mathrm{SnO}_{2} \cdot \mathrm{xH}_{2} \mathrm{O}, \mathrm{Sn}_{3} \mathrm{OSO}_{4}(\mathrm{OH})_{2}$ and $\mathrm{Sn}_{3} \mathrm{OCl}_{2}(\mathrm{OH})_{2}$. The logarithmic dependence of the area under the Mössbauer spectra shows the shape expected by Debye model: linear at high temperature. The slope of this curve at high temperature permits the determination of the Debye temperature and therefore the $f$ factor. Table 2 recapitulates the obtained results. 
The $f$-factor of crystalline industrial $\mathrm{SnO}_{2}$ has also been determined, see table 2, the obtained value is in good agreement with literature data [4]. The significant difference between this value and that obtained for $\mathrm{SnO}_{2} \cdot \mathrm{xH}_{2} \mathrm{O}(17 \%)$ shows that $f$-factor values obtained using industrial compounds can not be used for accurate quantitative analysis for corrosion products. Since the f-factor can be different for a same compound following its growth condition, it is necessary to determine systematically this factor for any quantitative purpose. Furthermore, the $f$-factor of tin compounds being low, it is pertinent to carry out Mössbauer measurement at low temperature in order to increase the sensitivity.

As regards to the f-factors found in this work, it appears difficult to detect small amount of $\mathrm{Sn}_{3} \mathrm{OSO}_{4}(\mathrm{OH})_{2}$ or $\mathrm{Sn}_{3} \mathrm{OCl}_{2}(\mathrm{OH})_{2}$ compounds if they are mixed with stannic oxide. The detection limit of Mössbauer spectroscopy is commonly defined as the amount corresponding to a sub-spectrum of at least $1 \%$ of the Mössbauer spectrum area. In this case, at room temperature, the detection limit can be evaluated as 1.57 mol. $\%$ and 1.54 mol.\% of sulfate and chloride respectively mixed with $\mathrm{SnO}_{2} \cdot \mathrm{xH}_{2} \mathrm{O}$.

\section{Conclusions}

Three tin corrosion products have been investigated by Mössbauer spectroscopy. The LambMössbauer factors of these compounds have been determined. The obtained $f$-factor values for these compounds are notably different. Consequently, the quantitative interpretation of the Mössbauer spectrum of a mixture of tin compounds must take into account this fact.

\section{References}

[1] Bill X. Huang, P. Tornatore and Ying-Sing Li, Electrochimica Acta, 46-5(2001)671.

[2] M. Zapponi, T. Pérez, C. Ramos, C. Saragovi, Hyp. Int. 148(2003)145

[3] A. H Muir. Mössbauer Effect and Methodology, vol. 4, ed I. J. Gruverman, Plenum Press, New York, 1968, p. 75.

[4] G.S. Collins, T. Kachnowski, N. Benczer-Koller, M. Pasternak, Phys. Rev. B 19(1979)1369.

[5] S. Jouen, B. Hannoyer and O. Piana. Surf. Interf. Anal. 34(2002)192.

[6] Dunkel, Stacie E., J.R. Craig, J.D. Rimstidt, and W.R. Lusardi, Canadian Mineralogist, 41(2003)659

[7] S. Jouen, Thesis, Université de Rouen, 2000.

[8] M.S. Moreno, R.C Mercader, Phys. Rev. B 50-14(1994)9875.

[9] C. D. Thiep, T.Bonchev, N. Chi Toa, S. Peneva, Bulg. J. Phys. Vol. 4-4(1977)399.

[10] M. Shibuay, K. Endo, K. Endo and H. Sano. Bult. Chem. Soc. Jap. Vol. 51- 5(1978)1363

[11] I. Lefebvre, M. A. Szymanski, J. Olivier-Fourcade, and J. C. Jumas, Phys. Rev. B 58(1998)1896

[12] C.G. Davies and J.D. Donaldson, J. Chem. Soc. A (1968)946.

[13] R. H. Herber and Y. Hazony, in Techniques of Chemistry, edited by A. Weissberger and B. W. Rossiter (Wiley, New York, 1972), Vol. I, p. 278ff. 


\section{Captions:}

Table 1 Hyperfine parameters at RT for $\mathrm{SnO}_{2} \cdot \mathrm{xH}_{2} \mathrm{O}, \mathrm{Sn}_{3} \mathrm{OSO}_{4}(\mathrm{OH})_{2}$ and $\mathrm{Sn}_{3} \mathrm{OCl}_{2}(\mathrm{OH})_{2}$

Figure 1. Mössbauer spectra at RT; (a) $\mathrm{SnO}_{2} \cdot \mathrm{xH}_{2} \mathrm{O}$, (b) $\mathrm{Sn}_{3} \mathrm{OSO}_{4}(\mathrm{OH})_{2}$ and (c) $\mathrm{Sn}_{3} \mathrm{OCl}_{2}(\mathrm{OH})_{2}$.

Figure 2.Temperature dependence of the normalised area under the resonance curve. $\mathrm{SnO} 2 . \mathrm{xH} 2 \mathrm{O}(\bullet), \mathrm{Sn}_{3} \mathrm{OSO}_{4}(\mathrm{OH})_{2}(\bullet)$ and $\mathrm{Sn}_{3} \mathrm{OCl}_{2}(\mathrm{OH})_{2}(+)$.

Table 2. Experimental $f$-factors and $\theta_{\mathrm{M}}$ for $\mathrm{SnO}_{2}, \mathrm{SnO}_{2} \cdot \mathrm{xH}_{2} \mathrm{O}, \mathrm{Sn}_{3} \mathrm{OSO}_{4}(\mathrm{OH})_{2}$ and $\mathrm{Sn}_{3} \mathrm{OCl}_{2}(\mathrm{OH})_{2}$. * deduced from $\theta_{\mathrm{M}}$ reference [4]

Table 1

\begin{tabular}{|c|c|c|c|}
\hline Compounds & $\delta \pm 0.005 \mathrm{~mm} . \mathrm{s}^{-1}$ & $\Gamma \pm 0.01 \mathrm{~mm} \mathrm{~s}^{-1}$ & $\Delta \pm 0.01 \mathrm{~mm}^{-\mathrm{s}^{-1}}$ \\
\hline $\mathrm{SnO}_{2} \cdot \mathrm{xH}_{2} \mathrm{O}$ & -0.001 & 1.02 & 0.61 \\
\hline $\mathrm{Sn}_{3} \mathrm{OSO}_{4}(\mathrm{OH})_{2}$ & 3.030 & 1.05 & 2.12 \\
\hline $\mathrm{Sn}_{3} \mathrm{OCl}_{2}(\mathrm{OH})_{2}$ & 3.244 & 0.91 & 1.72 \\
\hline
\end{tabular}

Table 1. Hyperfine parameters at RT for $\mathrm{SnO}_{2} \cdot \mathrm{xH}_{2} \mathrm{O}, \mathrm{Sn}_{3} \mathrm{OSO}_{4}(\mathrm{OH})_{2}$ and $\mathrm{Sn}_{3} \mathrm{OCl}_{2}(\mathrm{OH})_{2}$

Figure 1

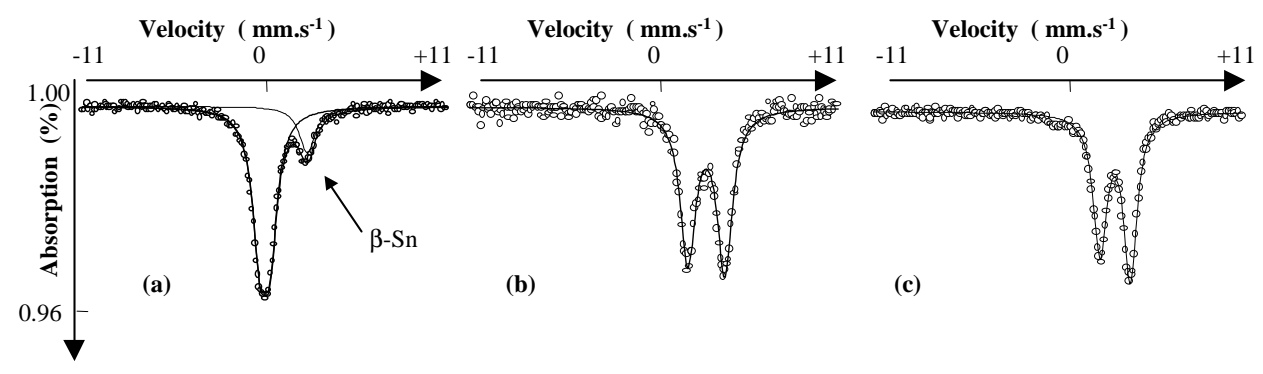

Figure 1. Mössbauer spectra at RT; (a) $\mathrm{SnO}_{2} \cdot \mathrm{xH}_{2} \mathrm{O}$, (b) $\mathrm{Sn}_{3} \mathrm{OSO}_{4}(\mathrm{OH})_{2}$ and (c) $\mathrm{Sn}_{3} \mathrm{OCl}_{2}(\mathrm{OH})_{2}$. 
Figure 2

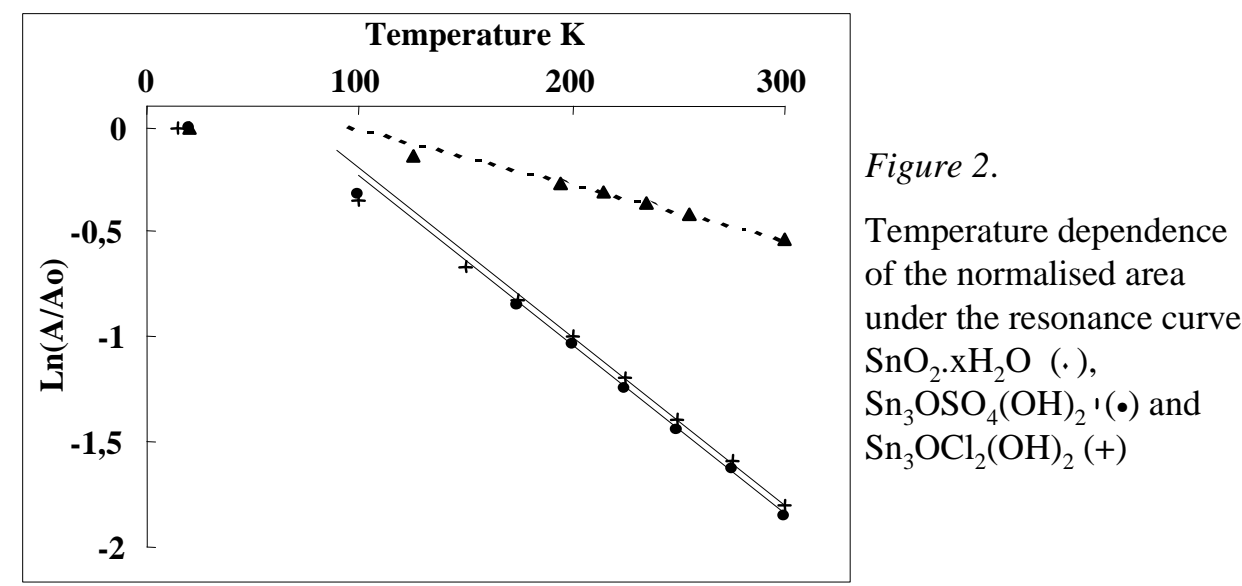

Table 2

\begin{tabular}{lcc}
\hline Compound & $\theta_{\mathrm{M}} \mathrm{K}$ & $f$-factor at RT \\
\hline $\mathrm{SnO}_{2} \cdot \mathrm{xH}_{2} \mathrm{O}$ & 265.3 & $0.45_{8}$ \\
$\mathrm{Sn}_{3} \mathrm{OCl}_{2}(\mathrm{OH})_{2}$ & 148.8 & $0.09_{8}$ \\
$\mathrm{Sn}_{3} \mathrm{OSO}_{4}(\mathrm{OH})_{2}$ & 147.0 & $0.09_{3}$ \\
$\mathrm{SnO}_{2}$ industrial & 310.3 & $0.56_{5}$ \\
$\mathrm{SnO}_{2}$ anhydrous & 313.0 & $0.57^{*}$ \\
$\mathrm{SnO}_{2}$ amorphous & 243.0 & $0.40^{*}$ \\
\hline
\end{tabular}

Table 2. Experimental $f$-factors and $\theta_{\mathrm{M}}$ for $\mathrm{SnO}_{2}, \mathrm{SnO}_{2} \cdot \mathrm{xH}_{2} \mathrm{O}$,

$\mathrm{Sn}_{3} \mathrm{OSO}_{4}(\mathrm{OH})_{2}$ and $\mathrm{Sn}_{3} \mathrm{OCl}_{2}(\mathrm{OH})_{2}$. * deduced from $\theta_{\mathrm{M}}$ reference [4] 